Article

\title{
Biodiversity Management under Cashew Agro-ecosystems in Central Africa: A case study from Cameroon
}

\author{
Djongmo Victor Awé ${ }^{1,}$, Noumi Valery Noiha ${ }^{2}$, Bi Tra Aimé Vroh ${ }^{3}$, Louis Zapfack ${ }^{4}$ \\ ${ }^{1}$ Faculty of Sciences, University of Ngaoundere, Cameroon \\ ${ }^{2}$ Higher Teacher Training College of Bertoua, University of Ngaoundere, \\ ${ }^{3}$ UFR BioSciences, University Félix Houphouët-Boigny, Abidjan, Côte d'Ivoire \\ ${ }^{4}$ Faculty of Sciences, University of Yaounde I, Cameroon \\ *Correspondence: awevictor20@yahoo.fr
}

How to cite this paper: Awé, D. V., Noiha, N. V., Vroh, B. T. A., \& Zapfack, L. (2021). Biodiversity Management under Cashew Agro-ecosystems in Central Africa: A Case Study from Cameroon. Open Journal of $\mathrm{Ag}$ ricultural Research, 1(2), 45-61. Retrieved from https://www.scipublications.com/journal/in-

dex.php/ojar/article/view/130

Received: August 2, 2021

Accepted: September 15, 2021

Published: September 16, 2021

Copyright: () 2021 by the authors. Submitted for possible open access publication under the terms and conditions of the Creative Commons Attribution (CC BY) license (http://creativecommons.org/licenses /by/4.0/).

\begin{abstract}
This study aimed to assess the floristic composition, vegetation structure and species associations of Cashew agro-ecosystems in the North region of Cameroon. The data were collected in $100 \mathrm{~m} \times 20 \mathrm{~m}$ transect methods. An analysis of the data collected in the field was conducted around the diversity and richness of the flora, but also the structure of Cashew agro-ecosystems. For the analyzes of vegetation structure, tree density, basal area and biovolume were calculated. The inventory included trees with a dbh greater than or equal to $5 \mathrm{~cm}$ on an area of 1 ha per plot. The experimental device installed is a complete random Fisher block with five repetitions. A total of 7849 individuals in 17 families, 20 genera and 38 species were recorded. Species Important value of vegetation cover indicated that Diospyros mespiliformis, Anogeissus leiocarpus, Annona senegalensis and Terminalia laxiflora are the most represented. Combretaceae are the most ecologically important families. Additionally, the grouping of species into four subdivisions showed that the Shannon diversity index varies from $2.18 \pm 0.09-3.47 \pm 0.17$ bits, Pielou index vary from $0.98 \pm 0.01-0.99 \pm 0.01$, Simpson's index ranges from $0.70 \pm 0.18-0.93 \pm 0.11$, density ranges from $102 \pm 1.92-128 \pm 6.36$ indiv/ha, basal area ranges from $2.02 \pm 0.31-12.68 \pm 2.01 \mathrm{~m}^{2} / \mathrm{ha}$, biovolume ranges from $11.58 \pm 1.29-68.03 \pm 13.21$ $\mathrm{m}^{3} /$ ha. The Sörensen similarity index is very high with floristic affinities greater than or equal to $90 \%$. The diameters and heights structure show a predominance of young individuals for the diameter and height classes on all plots. The most represented species associations are legumes (Arachis hypogeae: $40.54 \%$ ) and native fruit trees (Vitellaria paradoxa: $15 \%$ ). These results show the contribution of Cashew agro-ecosystems in biodiversity conservation.
\end{abstract}

Keywords: Agro-ecosystem; Biodiversity; Cashew

\section{Introduction}

Forest ecosystems of Central Africa in general and those of Cameroon in particular, are rich in natural resources [1]. They offer many opportunities to people for their livelihoods. However, faced with the implementation of the socio-economic development process, this environment is faced many threats, in particular, deforestation, degradation, poaching, pollution, overexploitation of biotic and abiotic resources, etc. Forest inventory and monitoring are key tools for understanding the structure, composition, diversity of different types of vegetation and habitats, and are also essential for achieving the goals of international agreements [1]. However, one of the most worrying environmental issues of the 21st century immediately after the climate change is deforestation [2]. The combined effects of this increasing human activity on natural resources in synergy with severe climatic factors continue to upset the natural balance within terrestrial ecosystems [2]. The 
degradation of forest ecosystems is a cause of the reduction in biodiversity in the world $[2,3,4]$. The Changes in the floristic composition and vegetation structure show this degradation [5]. These ecological disturbances, which affect the biological resources and the potentialities of the land, result in the deterioration of the standard of living of the populations.

Cashew (Anacardium occidentale L.) plantations occupy about 7.5 million hectares worldwide and are distributed in 32 countries [6,7]. The cashew nut-based agroforestry system in Tanzania, Mozambique, Nigeria, Guinea Bissau, Ivory Coast, Benin and Cameroon help solve the environmental and socio-economic problems of producers [8]. Indeed, the cashew is an economic crop grown on small farms because of the ease of cultivation $[9,10]$. Additionally, at the end of each nut-marketing year, the income obtained allows producers to organize ceremonies, acquire goods, services and the construction of housing $[11,12]$. According to the same authors, the presence of cashew tree plantations on farms contributes to the reduction of atmospheric carbon levels and promotes a healthy environment conducive to human development. From an ecological viewpoint, [11] has shown that agroforestry, especially cashew nut-based agroforestry developed by peasant populations in Northern Cameroon, is one of the most adequate solutions to mitigate the effects of environmental degradation. In this context, it has a positive impact on the dynamics of land use and is of ecological interest in the study area. However, beyond socioeconomic interests, cashew nut-based agroforestry, like other types, also offers ecological benefits in that it contributes to the reforestation of agricultural areas and reduces the roaming of producers in search of new land [13].

Additionally, cashew trees co-exist with other natural or planted plant species. Cashew agro-ecosystems can be places of refuge for plant biodiversity [11,14]. It is therefore important to study plant diversity within these ecosystems to better understand their power to conserve plant biodiversity. From a scientific viewpoint, the knowledge of the companion plant species of the cashew tree and the functioning of these agro-ecosystems constitutes a new line of research to be explored concerning the importance and rapid spread of this species in Cameroon. Thus, this study was initiated for the realization of the baseline study on the plant biodiversity of cashew agro-ecosystems in the North region of Cameroon, to lay the foundations for the sustainable management of these particular ecosystems. The cardinal point of this research is to appreciate the diversity of plant species evolving in the cashew nut based agroforestry.

\section{Materials and Methods}

\subsection{Study area}

The study occurred in Central Africa, more precisely in Cameroon, in the North region of Cameroon. This region is located between $8^{\circ} 00.0^{\prime} \mathrm{N}$ to $10^{\circ} 00.0^{\prime} \mathrm{N}$ latitude and $13^{\circ}$ $00.0^{\prime} \mathrm{E}$ to $15^{\circ} 00.0$ 'E longitude (Awé et al., 2021) (Figure 1). [15]. The relief is a vast plain between the Mandara Mountains (1442 $\mathrm{m}$ ) in the North and Adamawa plateau in the South [16]. The climate is of the Sudano-Sahelian type with two seasons: a dry season lasting six months (November-May) and a rainy season lasting six months (June-October) [11]. The average monthly temperature varies from $26^{\circ} \mathrm{C}$ in August to $40^{\circ} \mathrm{C}$ in March (extreme temperatures: $17^{\circ} \mathrm{C}$ to $40^{\circ} \mathrm{C}$ ) [17]. The soil is of the ferruginous type characterized by acidity ( $\mathrm{pH}=5.5$ to 6 ) and low cation exchange capacity [11]. The vegetation is a shrubby Sudanian savannah with a clear and degraded Savannah appearance around the villages [11]. Agriculture is the main activity of the people of the region. The population practices subsistence agriculture (corn, peanuts and millet) [11]. The administrative region 
of Northern Cameroon comprises four subdivisions, namely, Bénoué, Faro, Mayo Louti, and Mayo Rey (Figure 1).
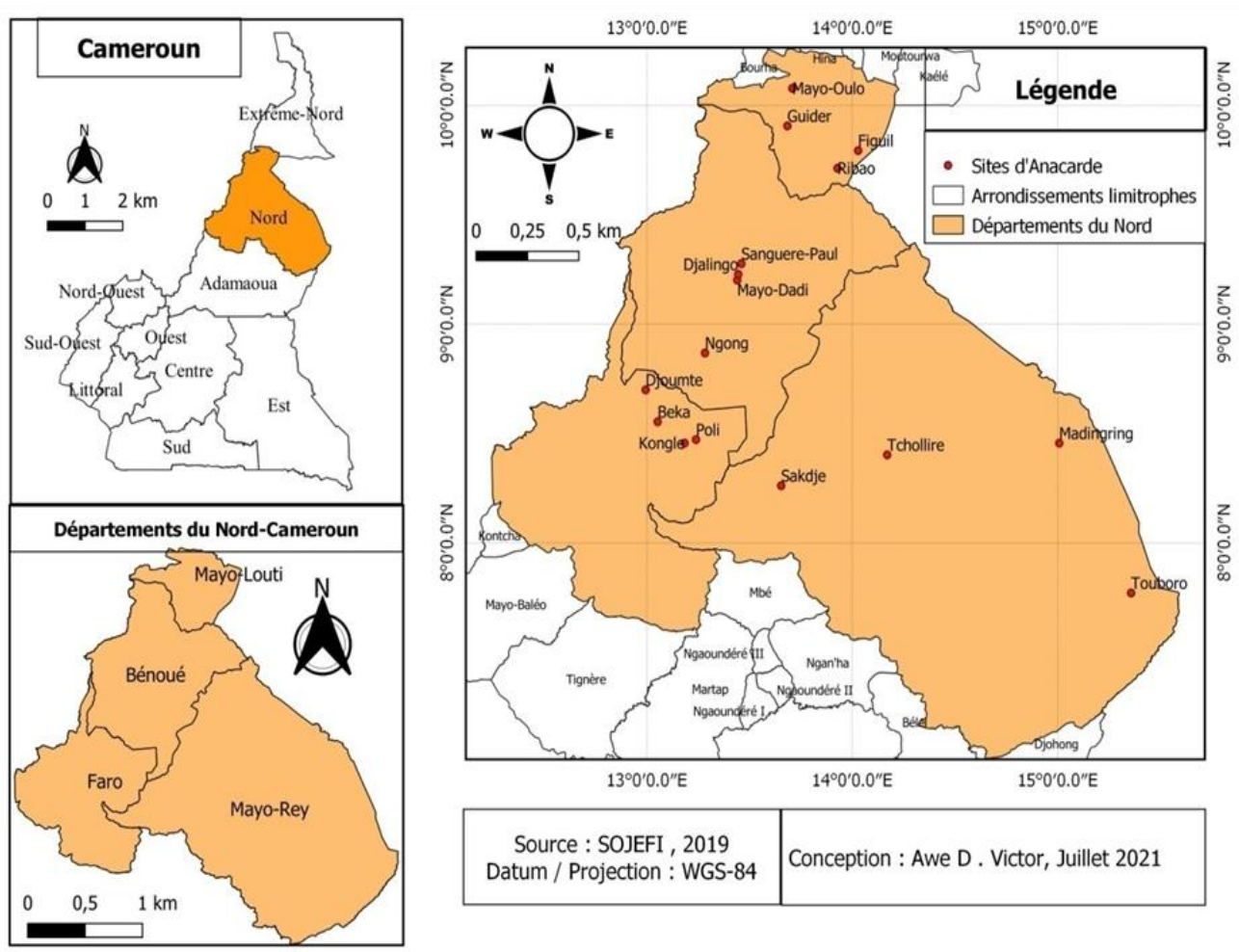

Figure 1. The geographic location of the study area in the North Region of Cameroon

\subsection{Choice of study sites and experimental design}

The choice of study station was based on the availability, age and area of cashew plantations. Three cashew plantations were selected according to age classes ( $0-10$ years; $10-20$ years and over 20 years). The survey was conducted among cashew producers. The IRAD fruit production subdivision in Garoua during the agricultural seasons from 2010 to 2018 records the targeted planters. The use of the report from IRAD in Garoua made it possible to get an idea of the situation in the areas. The choice of planters surveyed was made randomly among those with at least 1.5 hectares of agro-ecosystems. Thus, the investigation concerned 20 producers. The survey was conducted with a tool of the active method of participatory research and planning (the semi-structured interview). It occurred at home and/or in the field at the convenience of each planter. The purpose of the survey was to obtain information on the age of cashew agro-ecosystems in the study area. The experimental device installed is a complete random Fisher block with five repetitions. The four subdivisions (Bénoué, Faro, Mayo-Louti, Mayo-Rey) are considered main treatments. Three cashew plantations were selected according to age classes (0-10 years; $10-$ 20 years and over 20 years) chosen in each subdivision are considered secondary treatments. The five plots of $100 \mathrm{~m} \times 20 \mathrm{~m}$ as repetitions.

\subsection{Data collection}

Sampling methods consist of transects ranging from $100 \mathrm{~m}$ long to $20 \mathrm{~m}$ wide. The transects were installed in cashew plantations of three age groups at the end of making a comparison. A total of 5 transects were installed, representing a total sampling area of 1 
ha per site. The sampling bands were established using the compass, measuring tape, GPS and strings. At the ends of each strip, the stakes were planted equidistant from $20 \mathrm{~m}$ (Figure 2). Sampling is done in each $200 \mathrm{~m}^{2}$ strip to reduce counting errors. Along the transect, all woody species have been inventoried. The inventories of trees and shrubs were conducted by measuring their circumference with a tape measure. A transect corresponding to a survey, 60 surveys were conducted in the 12 plots of cashew trees sampled. As part of this work, the IUCN Red List has provided us with information on the status of the species inventoried. All the trees were systematically counted and measured. Dendrometric data focused on the measurement of the diameter at breast height (dbh)on bark using a tape measure and heightening a clinometer. Thus, the circumferences of the ligneous plants were measured using a tape measure at $1.30 \mathrm{~m}$ from the ground. The values of the circumference were then converted into diameter (dbh) according to the formula: $\mathrm{dbh}=$ $\mathrm{C} / \pi$, with $\mathrm{C}=$ circumference, $\mathrm{dbh}=$ diameter at breast height, and $\pi=3.14$. Several authors have used this sampling method $[11,18,19]$.

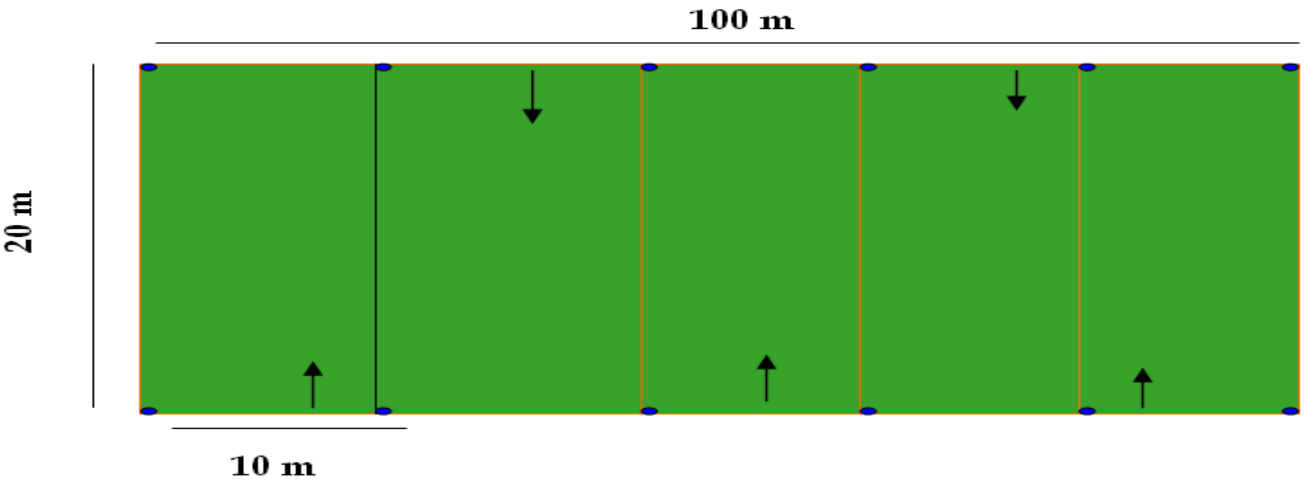

Figure 2. Illustration of the sampling method (100 m x $20 \mathrm{~m}$ transect for $\longrightarrow$ wood inventory in the $20 \mathrm{~m} \times 10 \mathrm{~m}$ strips). $=$ Picket).

\subsection{Data analyses}

The data have been encoded in the Excel software and then analyzed thanks to software Statgraphics Plus 5.0. Testing the significance was achieved thanks to ANOVA and Duncan test at 0.05 .

The analysis of plant diversity focused on

Species richness $(\mathrm{N}): \mathrm{N}=2^{\mathrm{H}} ; 2$ is the basis of the logarithm used to calculate the Shannon-Wiener's index $(\mathrm{H})$.

Shannon-Wiener's Index $(\mathrm{H}):=-\Sigma(\mathrm{ni} / \mathrm{Ni}){ }^{*} \log _{2}(\mathrm{ni} / \mathrm{Ni})$ with ni $=$ number of individuals of the species, $\mathrm{Ni}=$ total number of individuals; $\mathrm{H}$ is expressed in bit.

Piélou index $(\mathrm{E}):=\mathrm{H} / \log _{2} \mathrm{~N}$.

Sörensen similarity index: $S=(2 c) /(a+b) \times 100$ with $a=$ number of species in survey $1, b=$ number of species in survey $2, c=$ number of species common to both surveys.

Simpson's diversity index $(\mathrm{Ds})=1-[(\mathrm{ni}(\mathrm{ni}-1)) /(\mathrm{N}(\mathrm{N}-1)]$.

Density (D): $D=n / S$ where $D=$ Density (stems/ha), $n=$ total of individuals in a sample plot; $S=$ area of the sample plot (ha).

The Basal area $(\mathrm{Ba})$ of individual trees

$B A=\frac{\pi}{4} D^{2}$ Where $\mathrm{Ba}=$ basal area $\left(\mathrm{m}^{2} / \mathrm{ha}\right), \mathrm{D}=\mathrm{dbh}(\mathrm{cm})$ and $\pi=3.142$ (constant)

Biovolume is defined as the volume of wood provided by vegetation in a given area. It makes it possible to estimate the wood potential of plant formation. It is given by the formula of [37]: Biovolume $(\mathrm{V})=0.53 \sum \mathrm{Ba} \times \mathrm{h} \times \mathrm{n}$ with Ba: Basal area $\left(\mathrm{m}^{2} / \mathrm{ha}\right) . \mathrm{h}$ : the height 
of the barrel (m); $\mathrm{n}$ : total number of individuals; $\mathrm{V}$ : biovolume ( $\left.\mathrm{m}^{3} / \mathrm{ha}\right)$. According to [37], the biovolume is high when it is greater than $250 \mathrm{~m}^{3} /$ ha, medium when it is between 50 and $250 \mathrm{~m}^{3} / \mathrm{ha}$, and low, when it is less than $50 \mathrm{~m}^{3} / \mathrm{ha}$.

With $\sum \mathrm{Ba}$,: sum of basal area of individuals $\left(\mathrm{m}^{2} / \mathrm{ha}\right) ; \sum \mathrm{h}$ : sum of heights of individuals (m); $\sum \mathrm{n}$ : sum total of individuals; V: biovolume $\left(\mathrm{m}^{3} / \mathrm{ha}\right)$.

Relative frequency (RFi) was determined using the formula: $\mathrm{RFi}=\mathrm{AFi} / \mathrm{TF} \times 100$

Where AFi=Absolute frequency of species and TF = Total Frequency (Sum of AFi).

Relative density (RDi) was determined using the formula: $\mathrm{RDi}=\mathrm{ADi} / \mathrm{AD} \times 100$

Where $\mathrm{ADi}=$ Absolute density of species and $\mathrm{AD}=$ Absolute density.

Relative Dominance or Cover (RCi) was determined using the formula:

$\mathrm{RCi}=\mathrm{BAi} / \mathrm{TBA} \times 100$.

Where $\mathrm{BA} i=$ Basal area of species and TBA $=$ Total basal area.

Species Importance Value (SIV) of a species was calculated by adding the Relative frequency (RFi), Relative density (RDi) and Relative dominance (RCi).

The Family Importance Value Index (FIV) for botanical families was calculated by adding the IVI for different species of the same family.

\section{Vertical structure}

The distribution of woody individuals in diameter and height classes was conducted. Five diameter classes with amplitude equal to $15 \mathrm{~cm}$ have been established. Based on the results of height measurements, the individuals were grouped into $4 \mathrm{~cm}$ amplitude classes. All 5 classes were then simplified into large classes: regeneration, future stems, medium and large trees.

\section{Results}

\subsection{Species richness}

Within the four subdivisions, 7849 individuals were counted in all plots studied in this study. They are divided into 17 families represented by 20 genera and 38 species. Among the four subdivisions, cashew plantations in Bénoué subdivision have the greatest specific richness of undergrowth (24 species) (Table 1).

Table 1. Specific richness of the undergrowth in cashew agro-ecosystems.

\begin{tabular}{|c|c|c|c|c|c|}
\hline Subdivision & Ages (Years) & Species & $\begin{array}{c}\text { Gen- } \\
\text { era }\end{array}$ & Families & $\begin{array}{l}\text { Number of individu- } \\
\text { als }\end{array}$ \\
\hline \multirow{4}{*}{ Bénoué } & $0-10$ & 16 & 12 & 8 & 761 \\
\hline & $10-20$ & 20 & 15 & 8 & 880 \\
\hline & +20 & 25 & 17 & 13 & 932 \\
\hline & Total & 24 & 18 & 10 & 2573 \\
\hline \multirow{4}{*}{ Faro } & $0-10$ & 16 & 10 & 7 & 500 \\
\hline & $10-20$ & 18 & 12 & 8 & 593 \\
\hline & +20 & 21 & 15 & 10 & 705 \\
\hline & Total & 20 & 16 & 9 & 1798 \\
\hline \multirow{4}{*}{ Mayo-Loutii } & $0-10$ & 17 & 11 & 7 & 493 \\
\hline & $10-20$ & 20 & 16 & 9 & 555 \\
\hline & +20 & 22 & 18 & 10 & 634 \\
\hline & Total & 23 & 17 & 10 & 1682 \\
\hline \multirow{4}{*}{ Mayo-Rey } & $0-10$ & 13 & 9 & 6 & 508 \\
\hline & $10-20$ & 14 & 12 & 9 & 601 \\
\hline & +20 & 19 & 10 & 11 & 687 \\
\hline & Total & 19 & 13 & 8 & 1796 \\
\hline Gener & total & 38 & 20 & 17 & 7849 \\
\hline
\end{tabular}




\subsection{Species importance value (SIV)}

The woody undergrowth of cashew plantations that have a high value index (SIV) are Diospyros mespiliformis in Bénoué (SIV $=70.71 \%$ ), Anogeissus leiocarpus in the Faro (SIV $=49.57 \%)$, Annona senegalensis in the Mayo-Loutii (SIV $=61.28 \%)$ and Terminalia laxiflora in the Mayo-Rey $(\mathrm{SIV}=101.76 \%)$ subdivisions (Table2).

Table 2. Species importance Value.

\begin{tabular}{|c|c|c|c|c|c|}
\hline Subdivision & Species & $\mathrm{RCi}(\%)$ & RDi (\%) & RFi (\%) & $\operatorname{SIV}(\%)$ \\
\hline \multirow{11}{*}{ Bénoué } & Piliostigma thonningii & 1.12 & 6.39 & 8.39 & 15.91 \\
\hline & Terminalia schimperiana & 0.59 & 6.72 & 4.60 & 11.92 \\
\hline & Phyllanthus muellerianus & 0.43 & 5.66 & 5.66 & 11.76 \\
\hline & Detarium microcarpum & 13.81 & 20.71 & 34.71 & 69.23 \\
\hline & Diospyros mespiliformis & 18.40 & 23.10 & 29.20 & 70.71 \\
\hline & Annona senegalensis & 6.19 & 12.66 & 10.60 & 29.45 \\
\hline & Terminalia albida & 4.56 & 10.05 & 6.05 & 20.66 \\
\hline & Combretum adenogonium & 6.17 & 5.66 & 3.60 & 15.45 \\
\hline & Gardenia aqualla & 2.79 & 2.82 & 6.82 & 12.44 \\
\hline & Terminalia laxiflora & 3.75 & 1.63 & 5.62 & 11.00 \\
\hline & Other species & 1.47 & 10 & 20 & 31.47 \\
\hline \multirow{11}{*}{ Faro } & Combretum collinum & 8.45 & 14.25 & 16.15 & 38.85 \\
\hline & Vitellaria paradoxa & 8.26 & 10.47 & 12.47 & 31.21 \\
\hline & Piliostigma thonningii & 4.78 & 9.90 & 7.50 & 22.19 \\
\hline & Faidherbia albida & 11.22 & 4.14 & 2.10 & 17.48 \\
\hline & Balanites aegyptiaca & 5.82 & 10.00 & 8.06 & 23.89 \\
\hline & Burkea africana & 10.38 & 1.27 & 3.27 & 14.94 \\
\hline & Sterculia setigera & 10.52 & 0.30 & 0.30 & 11.13 \\
\hline & Anogeissus leiocarpus & 44.08 & 0.20 & 0.28 & 49.57 \\
\hline & Guiera senegalensis & 8.18 & 4.50 & 2.46 & 15.16 \\
\hline & Prosopis africana & 34.31 & 0.62 & 0.60 & 35.53 \\
\hline & Other species & 30.05 & 6.6 & 8.4 & 40.05 \\
\hline \multirow{8}{*}{ Mayo-Loutii } & Acacia seyal & 21.49 & 11.61 & 9.55 & 42.67 \\
\hline & Lannea schimperi & 5.16 & 18.88 & 16.80 & 40.85 \\
\hline & Annona senegalensis & 44.65 & 7.24 & 9.30 & 61.28 \\
\hline & Albizia zygia & 36.67 & 6.96 & 8.80 & 52.43 \\
\hline & Vitex domiana & 4.38 & 14.70 & 10.70 & 29.79 \\
\hline & Khaya senegalensis & 7.72 & 8.40 & 5.46 & 20.59 \\
\hline & Detarium microcarpum & 3.05 & 5.80 & 7.88 & 16.73 \\
\hline & Other species & 5.00 & 13.36 & 17.30 & 35.66 \\
\hline \multirow{7}{*}{ Mayo-Rey } & Terminalia laxiflora & 36 & 36.96 & 28.8 & 101.76 \\
\hline & Sterculia setigera & 14.38 & 24.7 & 20.7 & 59.78 \\
\hline & Faidherbia albida & 10.45 & 17.05 & 16 & 43.5 \\
\hline & Piliostigma reticulatum & 16.07 & 10.12 & 13.6 & 39.79 \\
\hline & Sclerocarya birrea & 11.79 & 2.82 & 10.7 & 25.31 \\
\hline & Ximenia americana & 10 & 1.63 & 5.6 & 17.23 \\
\hline & Other species & 1.31 & 6.72 & 4.6 & 12.63 \\
\hline
\end{tabular}

Note: RFi: Relative frequency; RDi: Relative density; RCi: Relative Dominance or Cover; SIV:Species Importance Value 


\subsection{Species importance value (SIV)}

Combretaceae have the highest family importance values in all four subdivisions: Bénoué (FIV=89.35 \%), Faro (FIV=79.98 \%), Mayo-Loutii (FIV= $77.09 \%$ ) and Mayo-Rey (71.53\%) (Table 3).

Table 3. Families Importance Value (FIV).

\begin{tabular}{|c|c|c|c|c|c|}
\hline Subdivision & Families & RFi (\%) & RDi (\%) & RCi (\%) & FIV (\%) \\
\hline \multirow{10}{*}{ Bénoué } & Combretaceae & 29.21 & 32.03 & 28.09 & 89.35 \\
\hline & Euphorbiaceae & 0.43 & 4.60 & 6.72 & 11.76 \\
\hline & Caesalpiniaceae & 1.500 & 20.58 & 14.50 & 36.59 \\
\hline & Rhamnaceae & 2.59 & 4.70 & 2.74 & 10.04 \\
\hline & Sapotaceae & 0.39 & 2.20 & 8.24 & 10.85 \\
\hline & Anacardiaceae & 6.03 & 9.32 & 5.30 & 20.66 \\
\hline & Annonaceae & 10.74 & 17.10 & 11.14 & 38.98 \\
\hline & Mimosaceae & 16.15 & 16.60 & 10.62 & 43.38 \\
\hline & Burseraceae & 4.66 & 10.53 & 4.49 & 19.70 \\
\hline & Other families & 5.61 & 8.50 & 3.58 & 18.69 \\
\hline \multirow{9}{*}{ Faro } & Combretaceae & 24.62 & 30.74 & 24.60 & 79.98 \\
\hline & Euphorbiaceae & 18.42 & 10.73 & 16.53 & 45.70 \\
\hline & Caesalpiniaceae & 18.65 & 4.40 & 6.59 & 29.64 \\
\hline & Annonaceae & 9.01 & 0.42 & 4.30 & 13.75 \\
\hline & Rubiaceae & 16.44 & 8.60 & 6.72 & 31.76 \\
\hline & Mimosaceae & 28.06 & 10.00 & 16.20 & 54.27 \\
\hline & Ebenaceae & 11.60 & 0.90 & 0.74 & 13.26 \\
\hline & Sapotaceae & 2.85 & 1.62 & 5.80 & 10.29 \\
\hline & Other families & 9.35 & 8.00 & 4.00 & 21.35 \\
\hline \multirow{9}{*}{ Mayo-Loutii } & Mimosaceae & 17.36 & 10.04 & 6.00 & 33.41 \\
\hline & Caesalpiniaceae & 4.42 & 3.04 & 9.04 & 16.50 \\
\hline & Euphorbiaceae & 4.42 & 10.00 & 2.08 & 16.50 \\
\hline & Combretaceae & 12.06 & 32.00 & 33.02 & 77.09 \\
\hline & Burseraceae & 10.76 & 4.00 & 0.06 & 14.83 \\
\hline & Verbenaceae & 4.38 & 12.60 & 8.80 & 25.79 \\
\hline & Malvaceae & 17.72 & 4.33 & 7.53 & 30.59 \\
\hline & Meliaceae & 10.05 & 13.04 & 7.20 & 30.31 \\
\hline & Other families & 24.50 & 10.28 & 20.10 & 54.98 \\
\hline \multirow{8}{*}{ Mayo-Rey } & Combretaceae & 21.09 & 30.2 & 20.24 & 71.53 \\
\hline & Anacardiaceae & 16.6 & 20.32 & 18.3 & 55.22 \\
\hline & Annonaceae & 16.03 & 15.3 & 18.3 & 49.63 \\
\hline & Euphorbiaceae & 3.06 & 9.1 & 17.15 & 29.31 \\
\hline & Burseraceae & 10.06 & 5 & 12.06 & 27.12 \\
\hline & Verbenaceae & 4.38 & 12 & 6.4 & 22.78 \\
\hline & Malvaceae & 16.72 & 4.33 & 4.53 & 25.58 \\
\hline & Other families & 12.06 & 3.75 & 3.02 & 18.83 \\
\hline
\end{tabular}

Note: RFi: Relative frequency; RDi: Relative density; RCi: Relative Dominance or Cover; FIV: Families Importance Value Index 


\subsection{Index of diversity in the undergrowth with cashew agroecosystems}

Shannon-Wiener's Index: The highest value of the Shannon-Wiener's Index was recorded in Cashew agro-ecosystems ( $2.93 \pm 0.50$ bits) of Mayo-Loutii subdivision. The analysis of variance shows that there are no significant differences in the Shannon-Wiener's Index between the age groups $(\mathrm{F}=0.22 ; \mathrm{P}=0.8138>0.05)$ and between the subdivisions $(\mathrm{F}=0.24 ; \mathrm{p}=0.8643>0.05)$ (Table 4$)$.

Piélou index: There is a Piélou index within species with a maximum value equal to 1. The analysis of variance shows that there are no significant differences in the Piélou index between the age groups $(\mathrm{F}=0.32 ; \mathrm{P}=0.7138>0.05)$ and between the subdivisions $(\mathrm{F}=0.34 ; \mathrm{p}=0.7043>0.05)$ (Table 4$)$.

Simpson's index: There is a Simpson index within species with a maximum value tending to 1 . Analysis of variance shows that there are no significant differences in the Simpson index between the age groups $(\mathrm{F}=0.164 ; \mathrm{P}=0.213>0.05)$ and between the subdivisions ( $\mathrm{F}=1.31 ; \mathrm{P}=0.3370>0.05)$ (Table 4$)$.

Importance Value Index: There is an Importance Value Index within species with a maximum value equal to $300 \pm 57.47$. The analysis of variance shows that there are no significant differences in the Importance Value Index between the age groups ( $\mathrm{F}=0.164$; $\mathrm{P}=0.286>0.05)$ and between the subdivisions $(\mathrm{F}=0.31 ; \mathrm{P}=0.3370>0.05)($ Table 4$)$.

Table 4. The index of diversity in Cashew agroecosystems.

\begin{tabular}{cccccc}
\hline Subdivision & Ages (Years) & ISH & EQ & DS & IVI \\
\cline { 2 - 5 } & $0-10$ & $2.28 \pm 0.07 \mathrm{a}$ & $0.98 \pm 0.01 \mathrm{a}$ & $0.75 \pm 0.15 \mathrm{a}$ & $300 \pm 57.47 \mathrm{a}$ \\
& $10-20$ & $2.95 \pm 0.06 \mathrm{a}$ & $0.99 \pm 0.01 \mathrm{a}$ & $0.86 \pm 0.12 \mathrm{a}$ & $300 \pm 57.47 \mathrm{a}$ \\
Bénoué & +20 & $3.47 \pm 0.17 \mathrm{a}$ & $0.98 \pm 0.01 \mathrm{a}$ & $0.93 \pm 0.11 \mathrm{a}$ & $300 \pm 57.47 \mathrm{a}$ \\
\cline { 2 - 5 } Faro & Mean & $2.90 \pm 0.59 \mathrm{~A}$ & $0.98 \pm 0.05 \mathrm{~A}$ & $0.84 \pm 0.09 \mathrm{~A}$ & $300 \pm 57.47 \mathrm{~A}$ \\
\hline \multirow{5}{*}{ Mayo-Loutii } & $0-10$ & $2.29 \pm 0.06 \mathrm{a}$ & $0.98 \pm 0.01 \mathrm{a}$ & $0.75 \pm 0.15 \mathrm{a}$ & $300 \pm 57.47 \mathrm{a}$ \\
& $10-20$ & $2.70 \pm 0.06 \mathrm{a}$ & $0.99 \pm 0.01 \mathrm{a}$ & $0.80 \pm 0.10 \mathrm{a}$ & $300 \pm 57.47 \mathrm{a}$ \\
& +20 & $3.42 \pm 0.06 \mathrm{a}$ & $0.98 \pm 0.01 \mathrm{a}$ & $0.88 \pm 0.14 \mathrm{a}$ & $300 \pm 57.47 \mathrm{a}$ \\
\cline { 2 - 5 } & Mean & $2.80 \pm 0.57 \mathrm{~A}$ & $0.98 \pm 0.05 \mathrm{~A}$ & $0.81 \pm 0.06 \mathrm{~A}$ & $300 \pm 57.47 \mathrm{~A}$ \\
\hline & $0-10$ & $2.43 \pm 0.05 \mathrm{a}$ & $0.98 \pm 0.01 \mathrm{a}$ & $0.78 \pm 0.15 \mathrm{a}$ & $300 \pm 57.47 \mathrm{a}$ \\
& $10-20$ & $2.95 \pm 0.09 \mathrm{a}$ & $0.99 \pm 0.01 \mathrm{a}$ & $0.86 \pm 0.12 \mathrm{a}$ & $300 \pm 57.47 \mathrm{a}$ \\
& +20 & $3.43 \pm 0.16 \mathrm{a}$ & $0.98 \pm 0.01 \mathrm{a}$ & $0.90 \pm 0.17 \mathrm{a}$ & $300 \pm 57.47 \mathrm{a}$ \\
\hline \multirow{5}{*}{ Mayo-Rey } & Mean & $2.93 \pm 0.50 \mathrm{~A}$ & $0.98 \pm 0,05 \mathrm{~A}$ & $0.84 \pm 0.06 \mathrm{~A}$ & $300 \pm 57.47 \mathrm{~A}$ \\
\hline & $0-10$ & $2.18 \pm 0.09 \mathrm{a}$ & $0.98 \pm 0.01 \mathrm{a}$ & $0.70 \pm 0.18 \mathrm{a}$ & $300 \pm 57.47 \mathrm{a}$ \\
& $10-20$ & $2.25 \pm 0.09 \mathrm{a}$ & $0.99 \pm 0.01 \mathrm{a}$ & $0.72 \pm 0.12 \mathrm{a}$ & $300 \pm 57.47 \mathrm{a}$ \\
& +20 & $3.29 \pm 0.06 \mathrm{a}$ & $0.98 \pm 0.01 \mathrm{a}$ & $0.82 \pm 0.15 \mathrm{a}$ & $300 \pm 57.47 \mathrm{a}$ \\
\hline & Mean & $2.57 \pm 0.62 \mathrm{~A}$ & $0.98 \pm 0.05 \mathrm{~A}$ & $0.74 \pm 0.06 \mathrm{~A}$ & $300 \pm 57.47 \mathrm{~A}$ \\
\hline
\end{tabular}

Note: ISH: Shannon's Index; EQ: Piélou index; DS: Simpson's Index; IVI: Importance Value Index. The assigned values of the same letter are not statistically different ( $p>0.05$, Duncan's test).

\subsection{Floristic similarity}

The Sörensen similarity index is very high with floristic affinities greater than or equal to $90 \%$ (Table 5). 
Table 5. Similarity Coefficients.

\begin{tabular}{|c|c|c|c|c|c|c|c|c|c|c|c|c|c|}
\hline \multirow[b]{2}{*}{ Subdivision } & \multirow[b]{2}{*}{ Parcelles } & \multicolumn{3}{|c|}{ Bénoué } & \multicolumn{3}{|c|}{ Faro } & \multicolumn{3}{|c|}{ Mayo-Loutii } & \multicolumn{3}{|c|}{ Mayo-Rey } \\
\hline & & PA1 & PA2 & PA3 & PA1 & $\mathrm{PA} 2$ & PA3 & PA1 & PA2 & PA3 & PA1 & PA2 & PA3 \\
\hline \multirow{3}{*}{ Bénoué } & PA1 & 100 & & & & & & & & & & & \\
\hline & PA2 & 93.98 & 100 & & & & & & & & & & \\
\hline & PA3 & 90.54 & 96.64 & 100 & & & & & & & & & \\
\hline \multirow{3}{*}{ Faro } & PA1 & 97.33 & 90.84 & 95.54 & 100 & & & & & & & & \\
\hline & PA2 & 90.54 & 97.88 & 93.80 & 95.71 & 100 & & & & & & & \\
\hline & PA3 & 95.5 & 96.96 & 97.50 & 91.04 & 95.54 & 100 & & & & & & \\
\hline \multirow{3}{*}{ Mayo-Loutii } & PA1 & 91.82 & 93.34 & 90.76 & 90.73 & 90.76 & 93.98 & 100 & & & & & \\
\hline & PA2 & 93.03 & 97.62 & 94.59 & 95.92 & 94.59 & 90.54 & 96.12 & 100 & & & & \\
\hline & PA3 & 90.44 & 93.78 & 98.94 & 93.32 & 98.94 & 97.33 & 98.98 & 95.74 & 100 & & & \\
\hline \multirow{3}{*}{ Mayo-Rey } & PA1 & 97.98 & 97.04 & 90.06 & 94.03 & 90.06 & 9054 & 96.93 & 95.08 & 90.92 & 100 & & \\
\hline & PA2 & 94.55 & 98.09 & 96.67 & 97.04 & 96.67 & 93.34 & 95.54 & 96.14 & 94.84 & 93.54 & 100 & \\
\hline & PA3 & 91.27 & 94.03 & 97.96 & 92.04 & 97.96 & 97.62 & 93.74 & 90.92 & 98.44 & 94.03 & 96.08 & 100 \\
\hline
\end{tabular}

Note:PA1: 0-10 years old; PA2: 10-20 years old; PA3: + 20 years old

\subsection{Vegetation structure index}

Density: The highest value of the density was recorded in Cashew agro-ecosystems $(125 \pm 2.64 \mathrm{indiv} / \mathrm{ha})$ of Bénoué subdivision. The analysis of variance shows that there is no significant difference in the density of plantations within the four subdivisions $(\mathrm{F}=$ 3.73; $\mathrm{P}=0.0606>0.05$ ) (Table 6).

Basal area: The highest value of the basal area was recorded in Cashew agro-ecosystems $\left(8.43 \pm 4.91 \mathrm{~m}^{2} / \mathrm{ha}\right)$ of Bénoué subdivision. The analysis of variance shows that there is no significant difference in the average basal area of plantations between the four subdivisions $(\mathrm{F}=0.19 ; \mathrm{P}=0.9035>0.05)$ (Table 6).

Biovolume: The highest value of the biovolume was recorded in Cashew agro-ecosystems $\left(8.43 \pm 4.91 \mathrm{~m}^{3} / \mathrm{ha}\right)$ of Bénoué subdivision. The analysis of variance shows that there is no significant difference in the average biovolume of the plantations within the four subdivisions $(\mathrm{F}=0.08 ; \mathrm{P}=0.9688>0.05)$ (Table 6).

Table 6. The vegetation structure index.

\begin{tabular}{ccccc}
\hline Subdivision & Ages (Years) & Density (indiv/ha) & Basal area $\left(\mathrm{m}^{2} / \mathrm{ha}\right)$ & Biovolume $\left(\mathrm{m}^{3} / \mathrm{ha}\right)$ \\
\hline \multirow{3}{*}{ Bénoué } & $0-10$ & $128 \pm 6.36 \mathrm{e}$ & $3.05 \pm 0.84 \mathrm{~b}$ & $16.70 \pm 3.41 \mathrm{c}$ \\
& $10-20$ & $124 \pm 1.78 \mathrm{~d}$ & $9.58 \pm 0.99 \mathrm{f}$ & $43.69 \pm 5.09 \mathrm{f}$ \\
& +20 & $123 \pm 1.81 \mathrm{~d}$ & $12.68 \pm 2.01 \mathrm{~h}$ & $68.03 \pm 13.21 \mathrm{~h}$ \\
& Mean & $125 \pm 2.64 \mathrm{~B}$ & $8.43 \pm 4.91 \mathrm{~A}$ & $42.80 \pm 25.67 \mathrm{~A}$ \\
\hline \multirow{2}{*}{ Faro } & $0-10$ & $119 \pm 4.32 \mathrm{c}$ & $2.17 \pm 0.20 \mathrm{a}$ & $13.94 \pm 0.74 \mathrm{~b}$ \\
& $10-20$ & $112 \pm 4.69 \mathrm{~b}$ & $5.91 \pm 0.90 \mathrm{~cd}$ & $26.08 \pm 6.01 \mathrm{~d}$ \\
& +20 & $102 \pm 2.82 \mathrm{a}$ & $10.11 \pm 1.31 \mathrm{fg}$ & $59.88 \pm 20.39 \mathrm{~g}$ \\
& Mean & $111 \pm 8.54 \mathrm{~A}$ & $6.06 \pm 3.97 \mathrm{~A}$ & $33.30 \pm 23.80 \mathrm{~A}$ \\
\hline \multirow{3}{*}{ Mayo-Loutii } & $0-10$ & $114 \pm 1.87 \mathrm{~b}$ & $2.02 \pm 0.31 \mathrm{a}$ & $11.58 \pm 1.29 \mathrm{a}$ \\
& $10-20$ & $102 \pm 1.92 \mathrm{a}$ & $5.06 \pm 0,37 \mathrm{c}$ & $25.56 \pm 1.74 \mathrm{~d}$ \\
& +20 & $111 \pm 1.64 \mathrm{~b}$ & $11.34 \pm 2.72 \mathrm{~g}$ & $67.85 \pm 19.18 \mathrm{~h}$ \\
& Mean & $109 \pm 6.24 \mathrm{~A}$ & $6.14 \pm 4.75 \mathrm{~A}$ & $34.99 \pm 29.29 \mathrm{~A}$ \\
\hline \multirow{2}{*}{ Mayo-Rey } & $0-10$ & $122 \pm 1.30 \mathrm{~cd}$ & $2.85 \pm 0.14 \mathrm{ab}$ & $14.30 \pm 0.47 \mathrm{~b}$ \\
& $10-20$ & $111 \pm 0.83 \mathrm{~b}$ & $7.09 \pm 1.89 \mathrm{e}$ & $33.13 \pm 11.44 \mathrm{e}$
\end{tabular}




\begin{tabular}{cccc}
\hline+20 & $110 \pm 2.86 \mathrm{~b}$ & $10.86 \pm 2.90 \mathrm{~g}$ & $60.00 \pm 20.80 \mathrm{~g}$ \\
Mean & $114 \pm 6.65 \mathrm{AB}$ & $6.93 \pm 4.00 \mathrm{~A}$ & $35.91 \pm 22.96 \mathrm{~A}$ \\
\hline
\end{tabular}

The assigned values of the same letter are not statistically different ( $\mathrm{p}>0.05$, Duncan's test).

\subsection{Distribution by diameter class}

The analysis of this figure shows that all distributions have a bell shape and fit better to a polynomial function of degree three. These four distributions have determination coefficients $\left(\mathrm{R}^{2}\right)$ ranging from 0.930 to 0.968 . The distribution is then asymmetric positive or asymmetric right, characteristic of monospecific stands with a predominance of young or small-diameter individuals, centered on the class] $15-25 \mathrm{~cm}]$. The analysis of variance shows that there is a highly significant difference $(p<0.01<0.05)$ in the diameter class. Indeed, in all four subdivisions, most populations are made up of individuals between 15 and $25 \mathrm{~cm}$ in diameter $(60.55 \%)$. The classes 5 to $15 \mathrm{~cm} ; 25$ to $35 \mathrm{~cm}$ and 35 to $45 \mathrm{~cm}$ represent $17.15 \%, 10 \%$ and $7.82 \%$ of the population, respectively, while individuals larger than $45 \mathrm{~cm}$ in diameter are poorly represented (4.48\%) (Figure 3).
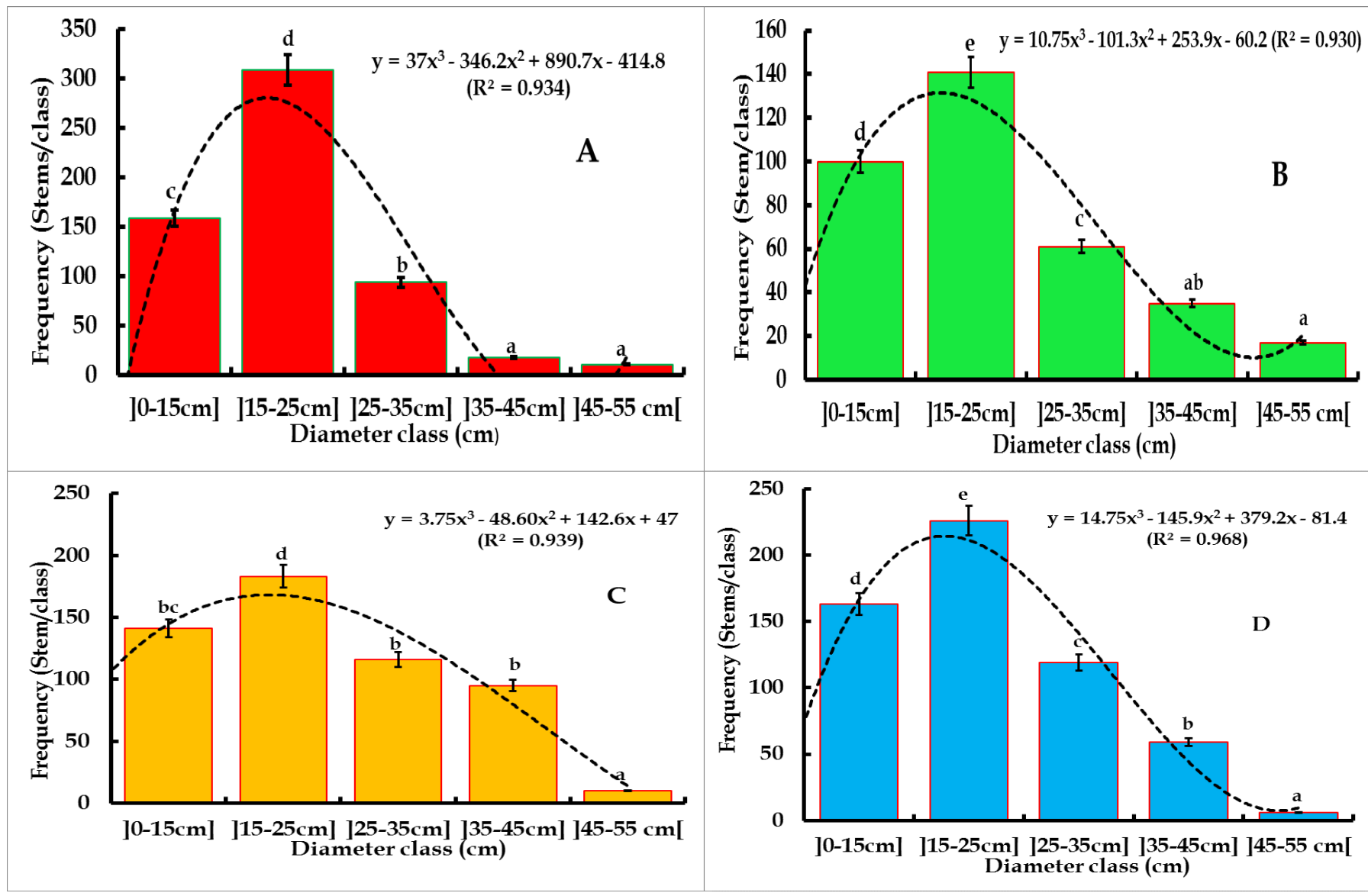

Figure 3: Distribution by diameter class according to the frequency of cashew trees' feet. A: Bénoué; B: Faro; C: Mayo-Loutii; D: Mayo-Rey. The assigned values of the same letter are not statistically different ( $p>0.05$, Duncan's test).

\subsection{Distribution by total height class}

The analysis of this figure shows that the distributions have a closed form and adapt better to a polynomial function of degree three. These four distributions have determination coefficients $\left(\mathrm{R}^{2}\right)$ ranging from 0.728 to 0.998 . Like the diametric structure, the distri- 
bution by total height class of cashew plantations in the four subdivisions shows a predominance of young feet. Trees in the total height class] 5-9 $\mathrm{m}$ ] is the most dominant. The analysis of variance shows that there is a highly significant difference $(\mathrm{p}<0.01<0.05)$ in the diameter class. Indeed, in all four subdivisions, individuals in the 5 to $9 \mathrm{~m}$ height class are in the majority (68.69 \%), followed by those in the 1 to $5 \mathrm{~m}$ class $(17.95 \%)$. The $9-13 \mathrm{~m}$ and more than $13 \mathrm{~m}$ classes represent $10.74 \%$ and $2.62 \%$ of the stand, respectively (Figure 4 ).
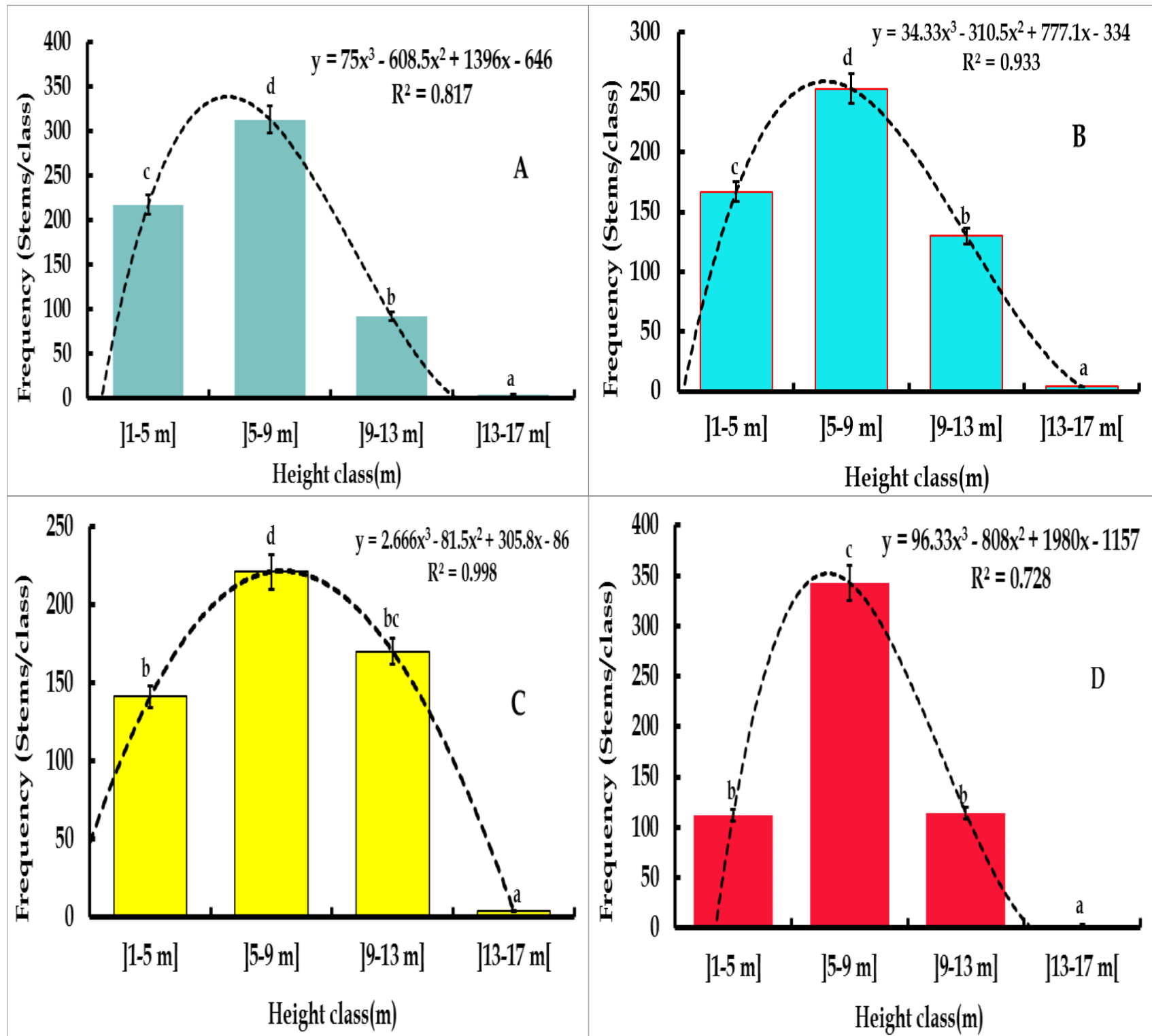

Height class $(\mathrm{m})$

Figure 4. Distribution by total height class according to the frequency of cashew trees' feet. A: Bénoué; B: Faro; C: Mayo-Loutii; D: Mayo-Rey. The assigned values of the same letter are not statistically different ( $\mathrm{p}>0.05$, Duncan's test).

\subsection{Species associations in cashew plantations}

\section{Fruit species found in plantations}

In addition to the associated annual species, some tree species co-exist with cashew seedlings. These are useful trees that were saved during the establishment of cashew orchards. In the four study subdivisions, Vitellaria paradoxa is the most dominant fruit tree $(15 \%)$ in the plots of different age groups (Figure 5). 


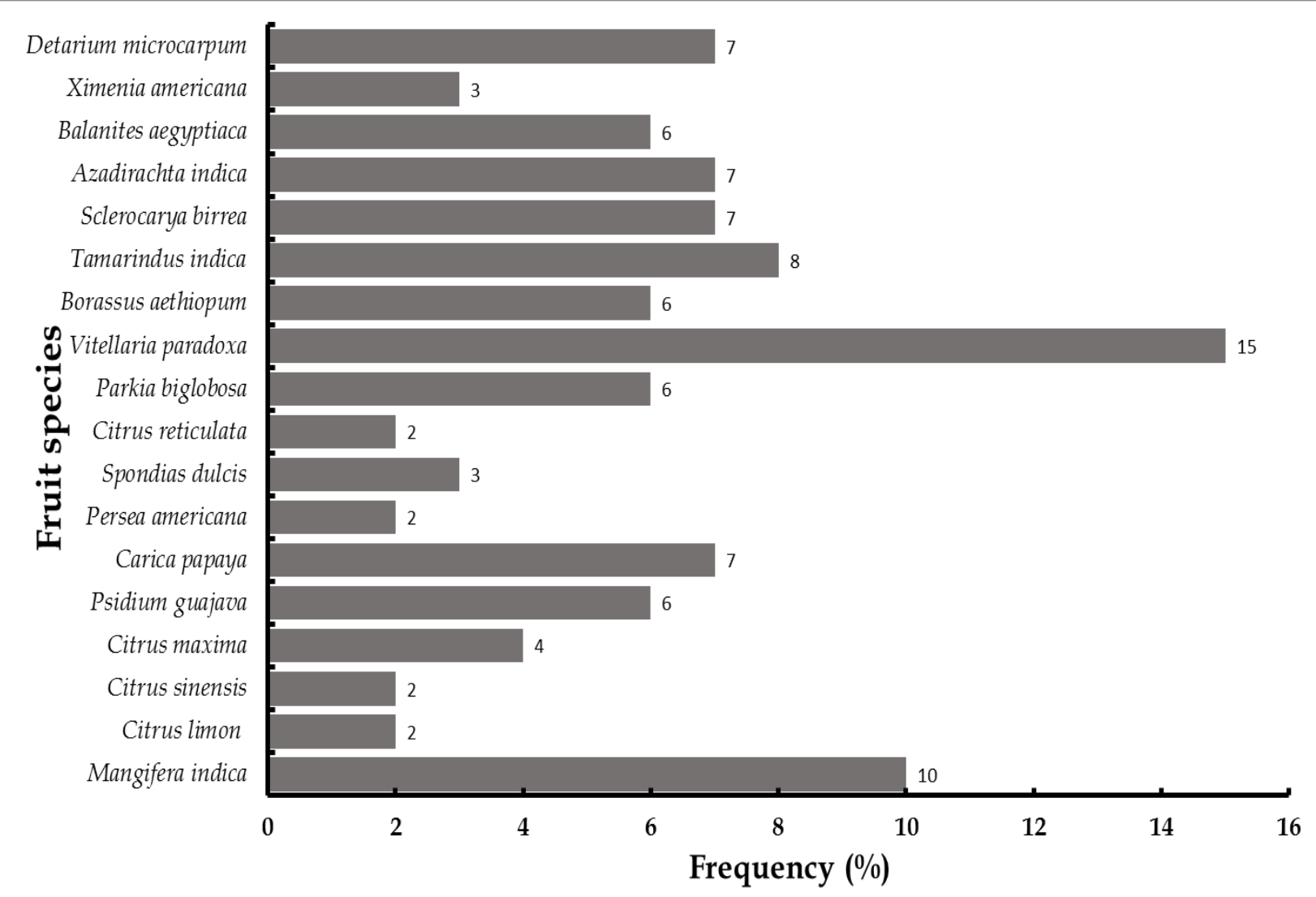

Figure 5. Representative of fruit species in cashew tree plantations in the four Study areas.

\subsection{Annual crops associated with the undergrowth of cashew plantations}

For the associations of annual crops in the undergrowth of cashew tree plantations studied in the four subdivisions, it appears that fourteen (14) species are the most cultivated, Arachis hypogea is the most cultivated $(40.54 \%)$ in the undergrowth of cashew tree plots. The Corchorus olitorius (10.4\%) is ranked third after Vigna unguiculata $(20.11 \%)$ (Table 7).

Table 7. The proportion of crops associated with cashew trees.

\begin{tabular}{ccc}
\hline Scientific Names & Families & Proportion (\%) \\
\hline Arachis hypogea & Fabaceae & 40.54 \\
Pennisetum glaucum & Poaceae & 2.45 \\
Zea mays & Poaceae & 2.7 \\
Glycine max & Fabaceae & 3.19 \\
Hibiscus esculentus & Malvaceae & 1.54 \\
Vigna unguiculata & Fabaceae & 20.11 \\
Sesamum indicum & Pedaliaceae & 1.89 \\
Vigna subterranea & Fabaceae & 1.65 \\
Dioscorea alata & Diocoreaceae & 1.58 \\
Manihot esculantus & Euphorbiaceae & 5.43 \\
Capsicum annuum & Solanacaeae & 1.33 \\
Corchorus olitorius & Tiliaceae & 10.4 \\
Ipomaea batatas & Convolvulaceae & 2.65 \\
Hibiscus sabdariffa & Malvaceae & 4.54 \\
\hline & &
\end{tabular}




\subsection{Species with special status}

The general list of species surveyed reveals 14 species of special status, representing $36.84 \%$ of all species surveyed. Among these species, 14 are cited as rare and endangered species of Cameroonian flora. These species are used by local communities for nutritional, medicinal and commercial purposes. It is necessary to promote education and awareness among local populations and to put in place measures for protection, enhancement and domestication of these endangered species (Table 8).

Table 8. Endangered species of IUCN (VU: Vulnerable; LR: Lower risk; EN: endanger; LC: Least concern)

\begin{tabular}{ccc}
\hline Species & Families & UICN Criteria \\
\hline Adansonia digitata & Bombacaceae & VU \\
Anogeissus leiocarpus & Combretaceae & VU \\
Khaya senegalensis & Meliaceae & VU \\
Sclerocarya birrea & Anacardiaceae & VU \\
Vitellaria paradoxa & Sapotaceae & VU \\
Ximenia americana & Olacaceae & VU \\
Detarium microcarpum & Fabaceae & LC \\
Entada africana & Leguminosae & LC \\
Prosopis africana & Fabaceae & LC \\
Tamarindus indica & Fabaceae & LC \\
Vitex doniana & Lamiaceae & LC \\
Balanites aegyptiaca & Balanitaceae & LR \\
Diospyros mespiliformis & Ebenaceae & EN \\
Erythrina sigmoida & Leguminosae & EN \\
\hline
\end{tabular}

\section{Discussion}

A total of 7849 individuals were counted in all plots in the four subdivisions studied in this study. They are divided into 17 families represented by 20 genera and 38 species. In terms of species diversity, the results of the inventories in the different plots show a lower diversity compared to the inventories of [11] identified 69 species comprising 31 families and 58 genera in cashew plantations in North Cameroon; in the Adamawa region, [20] respectively identified 70 species comprising 30 families, 53 genera in Eucalyptus sp plantations. Cashew plantations in the Bénoué subdivision are richer in phytodiversity (24 species). These results conclude that land management methods offer a significant floristic diversity that varies according to techniques, ages and regions. The importance value index of the different plots is of the order of 300 . The presence of tall trees in these plots explains the importance value index. This result leads to the same conclusion as those of $[19,21]$ who state that trees with large crowns contribute more to cover and to some degree of cover, they modify ecological conditions by reducing air evaporative power, promoting the soil water balance and improving fertility. This value is higher than that found in northern Cameroon by [11] who found 150. In the cashew plantations of the four subdivisions, Combretaceae is the most important, followed by the Mimosaceae and Caesalpiniaceae. These results are similar to those of $[22,23,24,25,26]$. Indeed, in the Combretaceae, we find species capable of resisting disturbances. This family is the most common and strongly represented in tropical countries, particularly in the savannah of Africa and more typically in the Sudano-Sahelian zone. Terminalia laxiflora is the best represented species and therefore has a better recovery, therefore is the most predominant species. 
The Shannon index is higher under plots of more than 20 years old in the Bénoué subdivision ( $3.47 \pm 0.17$ bits). This Shannon index indicates a medium diversity within the plant group under consideration, which means that the conditions at the station are favourable for the installation of a large number of species equal proportions. The value of the average Shannon index of the undergrowth of cashew plantations is less than 3 . These values show homogeneity and testify to a flora that is not diversified in the undergrowth of cashew trees. These results are relatively close to those of [11] to cashew agro-ecosystems of Cameroon. The Pielou equitability tends toward one in all plots being high represents the presence of no dominant species. These results are very far from those of [27] to cocoa agroecosystems (Cameroon). But are similar to those of [28] to Eucalyptus sp agroecosystems in the Adamawa region of Cameroon. These values reflect the presence of preexisting savannah species in the stands of the systems studied and these associated species are homogeneously and equitably distributed. The Simpson index is sensitive to the distribution of individuals between species. These values can also be interpreted as resulting from the effect of increased plant density, which is accompanied by an increase in species diversity after forest disturbances in tropical environments [3]. Simpson's index tends toward one in all plots. These results are similar to the values obtained by [29] in the agroforests of the peri-urban area of the city of Bafia (Central Region of Cameroon).A two-by-two comparison of the floristic composition of the four subdivisions, using Sorensen's method, indicates a similarity threshold greater than or equal to $90 \%$, thus showing that the different subdivisions studied are part of the same floristic ensemble. The pressure of timber exploitation exerted by the peasant populations explains the variation in the abundance of cashew tree plantations from one subdivision to another.

In comparing cashew plantations in the four subdivisions, note that cashew plantations in the Bénoué subdivision are denser (125 \pm 2.64 indiv/ha). These results are lower than the values of $200 \mathrm{indiv} / \mathrm{ha}, 250 \mathrm{indiv} / \mathrm{ha}, 475 \mathrm{indiv} / \mathrm{ha}, 225 \mathrm{indiv} / \mathrm{ha}$ obtained, respectively, by [30] in cashew plantations in the North-western, Southern, and Central of Benin. However, these results are close to the value of $100 \mathrm{indiv} / \mathrm{ha}$ and $139 \mathrm{indiv} / \mathrm{ha}$ obtained by [30] in cashew plantations in the Far North and North-West of Benin; But are higher than the value of 77 indiv/ha obtained by [31] in the Talba of Central Cameroon. They are also not close to those of [28] in Eucalyptus plantations (53.17 \pm 0.08 indiv/ha). In terms of age according to cashew tree stands, cashew tree plots over 20 years old in Bénoué subdivision are denser (123 $\pm 1.81 \mathrm{indiv} / \mathrm{ha})$. These results are higher than the values obtained by [11] to cashew trees over 20 years old $(38.64 \pm 47.42 \mathrm{indiv} / \mathrm{ha})$. The farmers' desire to provide plant cover, thus protecting it from light radiation and creating a microclimate favorable to the flowering of the cashew tree explains the differences observed between the plots studied and those of other authors. High density is observed in cashew trees $0-10$ years old in the Bénoué subdivision ( $128 \pm 6.36$ indiv/ha). This high density means that the stems that make it possible to reconstitute the environment are shrubs. In addition to the fruit trees left in the cashew trees, the dominance of cashew is responsible for the high density of the stems. Stand density and tree distribution patterns vary with topography, soil, exposure, silvigenetic stages, and human activity. The highest values of basal area are observed in plots older than 20 years. The existence of large tree specimens in plots over 20 years old explains the higher basal area values. The impact of human activities, such as the killing of individuals during clearing for the establishment of agricultural plots and the devastating actions of animals (cattle) explains the low values of basal area in the 0-10 year-old plots. These results are close to the values obtained by [11] to over 20 years old cashew tree plantations $\left(15.23 \pm 0.07 \mathrm{~m}^{2} / \mathrm{ha}\right)$. The ecological characteristics of the study environments, in particular the types of soil, topography, climate and cover, explain the differences in the basal area of the cashew agro-ecosystems studied. 
The highest biovolumes were recorded in cashew trees over 20 years old in Bénoué subdivision $\left(68.03 \pm 13.21 \mathrm{~m}^{3} / \mathrm{ha}\right.$ ), which means that these plots have a high wood potential due to their large diameters. The absence of anthropogenic activities in these cashew plots explains the high biovolume values. The results obtained in this study are much lower than the $428.68 \mathrm{~m}^{3} / \mathrm{ha} ; 285.57 \mathrm{~m}^{3} / \mathrm{ha} ; 105.66 \mathrm{~m}^{3} /$ ha found respectively by [32] in Agroforests, semi-deciduous dense forests and forest galleries and the wooded and shrubby savannas of the Akposso Plateau in the sub-humid zone in Togo.

The bell-shaped distribution skewed to the left, characterized by a decreasing distribution of individuals, from small diameter classes to large diameter classes. Germinations occurring in cohorts explain the strong presence of young individuals. This type of distribution is obtained by [33] in P. butyracea populations in the municipalities of Natitingou, Boukombé and Toucountouna, similar to that of Isoberlinia spp. tree / wooded savannas of the classified forest of Wari-Maro (Center Benin) by [34].

The height class distribution has a bell-shaped structure centered on the class] 5-9 m] reflecting a predominance of medium height individuals. Large individuals are more traumatized by humans and animals; being under anthropogenic pressure, they do not have the chance to grow, explain these results obtained. However, the bell-shaped structure is a sign that the ecosystem as a whole is in a state of degradation as also concluded by [28] after finding the same structure in the Eucalyptus sp agroecosystems of Adamawa in Cameroon.

The local species found in cashew tree plantations come from natural regeneration. They have socio-economic importance and the exploitation of their seeds generate substantial income. These results are similar to those of $[35,36]$ in the agroforestry from Cameroon. The productivity of corn grown under tree cover are below expectations. Good yields are only observed in agro-systems where all the trees are pruned. The plantations established have a soil cover rate that is not very favorable to the productivity of sunloving crops, which explains this situation. Associations are rare in cashew plantations after 10 years of planting. The reason is that according to the farmers, the land that houses these trees is poor, and that is what we have also found. The presence of special-status species, particularly in terms of their numbers (14), confirms the role that cashew plantations can play in conserving biodiversity in general. The significant and uncontrolled overexploitation has an influence on the presence of IUCN Red List species cited in this study.

\section{Conclusion}

The objective of this study is to demonstrate the effectiveness of Cashew agro-ecosystems in the food security of the populations, the conservation of phytodiversity. Cashew agro-ecosystems of North region (Cameroon) thus contain a remarkable high biodiversity. This study reveals a significant potential of even the most threatened taxa in the Sudano-Sahelian zone of Cameroon. Thus, 38 species belonging to 17 families represented by 20 genera are inferred from cashew plantations in the Sudano-Sahelian zone of Cameroon, which illustrates the conservative nature of the plant diversity of these agroecosystems. The presence of threatened plant species in these agro-ecosystems confirms their ecological usefulness and justifies the need for their conservation. Given the importance of this agro-ecosystem on the social, ecological and environmental levels, such systems are considered as factors of local development and guarantee food security for local populations. This study also showed that crops associated with cashew trees, mainly legumes and fruit trees, are important for increasing the productivity of these agro-ecosystems. The latter have indeed revealed a not insignificant floristic diversity but exposed to intense and continuous degradation that risks in the near future to make the species 
useful for humans disappear. In the end, these results are also of great economic, ecological and dynamic informative value that should serve as a basis for guiding any action program aimed at the conservation and management of these agroecosystems.

\section{Acknowledgments}

Our appreciation goes to the "Lamido" of the localities studied for the information that they kindly communicated in connection with the cashew plantations.

\section{Conflict of Interest}

The author declares that there is no conflict of interest regarding the publication of this manuscript.

Author Contributions: Conceptualization, D.V.A. and N.N.V.; methodology, D.V.A.; software, B.T.A.V.; validation, N.N.V., D.V.A and L.Z.; formal analysis, D.V.A.; investigation, L.; writingoriginal draft preparation, D.V.A.; writing-review and editing, B.T.A.V.; visualization, L.Z..; supervision, N.N.V and B.T.A.V. All authors have read and agreed to the published version of the manuscript.

Funding: This research received no external funding.

Acknowledgments: Our appreciation goes to the "Lamido" of the localities studied for the information that they kindly communicated in connection with the cashew plantations.

\section{References}

1. Moses N.S.; Nchu F.; Peterson A.T. (2020). Diversity, above-ground biomass, and vegetation patterns in a tropical dry forest in KimbiFungom National Park, Cameroon. Heliyon 6:e3290.

2. Garba A.; Amani A. ; Douma S. ; Sina A.K.S. ; Mahamane A. (2020). Structure des populations de Tamarindus indica L. dans la zone SudOuest du Niger. Int J Biol Chem Sci. 14(1): 126-142.

3. Awé D.V.; Noiha N.V.; Madou C.; Zapfack L. (2020a).Floristic composition, diversity and structure of Khaya senegalensis stands in Benue Subdivision, Cameroon. J Trop Resour Sustain Sci .8: 2462-2389.

4. Awé D.V.; Noiha N.V.; Zapfack L. (2020b).Carbon Storage and Emission Factor of Savanna Ecosystems in Sudano-Sahelian Zone of Cameroon. J Bot Res. 2(1):60-67.

5. Noiha N.V.;Zapfack L.; Hamadou M.R.; Awe D.V.; Witanou N.; Nyeck B.; Ngossomo J.D.; Tabue M.R.B.; Mapongmetsem P.M. (2018c) .Floristic diversity, carbon storage and ecological services of eucalyptus agrosystems in Cameroon. Agroforest Syst.92:239-50. DOI $10.1007 / \mathrm{s} 10457-017-0130-5$.

6. Balogoun I.; Ahoton E.L.; Saïdou A.; Bello D.O.; Amadji L.G.; Ahohuendo C.B.; Babatoundé S.; Chougourou C.D.; Ahanchede A. (2016). Effect of climatic factors on cashew (Anacardium occidentale L.) productivity in Benin (West-Africa). Journal of Earth Science \& Climate Change (JESCC). 7:329-338.

7. Seydou N. ; Mohamed M.C. ; Malaïny D. (2017).Caractérisation des Plantations à base d'anacardier (Anacardium occidentale L.) dans le Balantacounda : Cas des communes de Kaour, Goudomp et Djibanar (Casamance/Sénégal). European Scientific Journal. 13(12) :1857-7881.

8. Monteiro F.;Catarino L.; Batista D.; Indjai B.;Duarte M.C.; Romeiras M.M. (2017).Cashew as a High Agricultural Commodity in West Africa: Insights towards Sustainable Production in Guinea-Bissau.Sustainability. 9(9):1666; https://doi.org/10.3390/su9091666.

9. Monteiro F.; Romeiras M.M.; Figueiredo A.; Sebastiana M.; Baldé A.; Catarino L.; Batista D. (2015). Tracking cashew economically important diseases in the West African region using metagenomics. Front Plant Sci6:482.

10. Adeigbe O.O.; Olasupo F.O.; Adewale B.D.; Muyiwa A.A. (2015). A review on cashew research and production in Nigeria in the last four decades. Sci Res Essays. 10: 196-209.

11. NoihaN.V.;Zapfack L.;AwéD.V.;Witanou N.;Nyeck B.;Ngossomo J.D.;Hamadou M.R.;Chimi C.D.;Tabue M.R.B. (2017). Floristic structure and sequestration potential of cashew agroecosystems in Africa: Acase study from Cameroon..Journal of Sustainable Forestry.36(3): 277-288.

12. Arbonnier M. (2019).Trees, Shrubs and Vines of West Africa (4th edition). Éditions Quae, Hors Collection, 02689 NUM, Pages779.

13. Ollenburger M.H.; Descheemaeker K.; Crane T.A.; Sanogo O.M.; Giller K.E. (2016). Waking the Sleeping Giant: Agricultural intensification, extensification or stagnation in Mali's Guinea Savannah. Agric Syst.148:58-70.

14. Noiha N.V.; Zapfack L.; Ngueguim J.R.; Chimi D.C.; Awé D.V.; Ngossomo J.D.; Hamadou R.M.; Nyeck B.; Witanou N.;Tabue M.R.B. (2018b).Floristic Diversity and Structure of Cocoa Agro-ecosystems in Southeastern Cameroon.Journal of Agriculture and Ecology Research International.14 (4): 1-9.

15. Awé D.V.; Noiha N.V.; Zapfack L. (2020c). Floristic structure and ecological role of Rourea afzelii stand in three savannah ecosystems from Cameroon. J Trop Resour Sustain Sci.8:5-11.

16. Bourou S.; Adamou I. ; Madou C. ; Kuate J. (2019). Diagnostic du mode d'exploitation et contraintes majeures des vergers fruitiers et autres espèces arboricoles dans la région du Nord Cameroun. Int J Biol Chem Sci.13(1): 251-264.

17. Awé D.V.; Noiha N.V.; Zapfack L.; Ali A.D.; Madou C. (2019b) Carbon Stocks in Dead Wood Biomass of Savannah Ecosystems in Northern Region Cameroon. J Bot Res.2(1):60-70.

18. Noiha N.V.; Zapfack L.; Pelbara P.; Awe D.V.; Tabue M.R.B. (2018d). Afforestation/Reforestation Based on Gmelina Arborea (Verbenaceae) in Tropical Africa: Floristic and Structural Analysis, Carbon Storage and Economic Value (Cameroon). Sustainability in Environment.3 (2):161-176. 
19. Awé D.V.; Noiha N.V.; Zapfack L.; Vroh B.T.A.; Nyeck B. (2019c).Vegetation Structure, Root Biomass Distribution and Soil Carbon Stock of Savannah Agrosystems in Sudano-Sahelian Zone of Cameroon. J Bot Res 2(1):71-80.

20. Noumi V.; Zapfack L.; Bienvenu A.; Ngueguim J. R.; Djomo C. C.; Djongmo V.; Ngossomo J. D.; Hamadou R. M.; Nyeck B.; Witanou N.; Mbobda R. B. T. (2018). Floristic Diversity and Structure of Cocoa Agro-Ecosystems in Southeastern Cameroon. Journal of Agriculture and Ecology Research International. 14(4):1-9. https://doi.org/10.9734/JAERI/2018/28264.

21. Savadogo M.O. ; Ouattara K. ;Pare S. ;Ouedraogo I. ;Sawadogo K.S. ;Barron J. ; Zombre N.P. (2016).Structure, composition spécifique et diversité des ligneux dans deux zones contrastées en zone Sahélienne du Burkina Faso.Revue électronique des sciences de l'environnement. 16(1) :1492-8442.

22. Massaoudou M. ; Larwanou M. ; Mahamane S. (2015). Caractérisation des peuplements ligneux des parcs à Faidherbia albida (Del) A. Chev. et à Prosopis africana (Guill., Perrot et Rich.) Taub. du Centre-Sud Nigérien. Journal of Applied Biosciences. 94 :8890-8906.

23. Morou B. ; Ounani H. ; Abdoulaye A.O.; Diouf A. ; Guero C. ; Mahamane A. (2016). Caractérisation de la structure démographique des ligneux dans les parcs agroforestiers du terroir de Dan Saga (Aguié, Niger). Int J Biol Chem Sci.10 (3) :1295-1311.

24. Ousmane L.M. ; Oumarou B.G. ; Morou B. ; Karim S. ; Mahamane A. (2017). État de la végétation ligneuse au Sahel : Cas de Guidan Roumdji au sahel central du Niger. Journal of Animal \& Plant Sciences. 31(3) :5033-5049.

25. Barmo S. ; Amani A. ; Soumana I. ; Ichaou A. ; Karim S. ; Mahamane A. (2019). Structure et diversité des parcs agroforestiers adjacents à la forêt protégée de Baban Rafi, Niger - Afrique de l'Ouest. Afrique Science.15(2) : 166-185.

26. Souare K.; Abib F.C.; Wadjou B.D.; Ibrahima A. (2020). Floristic Composition of Woody Species and Potential Carbon Storage in Reforested Sites of Sudano-Sahelian Zone of Cameroon. International Journal of Scientific Research and Management (IJSRM). 08 (07): $2321-3418$ DOI: $10.18535 / \mathrm{Jjsrm} / \mathrm{v}$ 8i07.fe01.

27. Noiha N.V.; Zapfack L.; Mbade L.F. (2015). Biodiversity Management and Plant Dynamic in a Cocoa Agroforests (Cameroon). International Journal of Plant and Soil Science. 6 (2):101-108.

28. Noiha N.V.; Awé D.V.; Nyeck B.; Tabue M.R.B.;Zapfack L. (2018).Vegetation structure, carbon sequestration potential and species conservation in four agroforestry systems in Cameroon (Tropical Africa). Acta Botanica Brasilica. 32(2):212-221. Doi: 10.1590/0102-33062017abb0279.

29. Mapongmetsem P.M. ; Etchiké D. ; Ngassoum M.B. (2016). Conservation et valorisation de la biodiversité dans les agroforêts de la zone périurbaine de la ville Bafia (Région du Centre au Cameroun).Revue Scientifique et Technique Forêt et Environnement du Bassin du Congo. $6: 60-69$.

30. Bello O.D.; Saïdou A.; Ahoton E.L.; Avaligbé J.F.Y.; Ezin A.V.; Akponikpè P.B.I.; Aho N. (2017).Assessment of organic carbon stock in cashew plantations (Anacardium occidentale L.) in Benin (West Africa).International Journal of Agriculture and Environmental Research. 03(04): 3601-3625.

31. Madountsap T.N.; Zapfack L.; Chimi D.C.; Kabelong B.L.P.; Tsopmejio T.I.; Forbi P.F.; Ntonmen Y.A.F.; Nasang J.M. (2017). Biodiversity and Carbon Stock in the SODECAO Agroforestry System of Center Region of Cameroon: Case of Talba Locality. American Journal of Agriculture and Forestry.5 (4) :121-129. doi: 10.11648/j.ajaf.20170504.16.

32. Kombate B. ; Dourma M. ; Folega F. ; Woegan A.Y. ; Wala K. ; Akpagana K. (2019).Structure et potentiel de séquestration de carbone des formations boisées du Plateau Akposso en zone sub-humide au Togo. Afrique Science. 15(2):70-79.

33. Natta A. K. ; Adomou A.C.; Tchabi V.I. ; Sogbegnon A.R. ; Mensah G.A. ; Sinsin B.A. (2011 b). Inventaire, typologie et structure des populations naturelles de Pentadesma butyracea (Clusiaceae) de la chaîne de l'Atacora au Nord-Ouest du Bénin. Bulletin de la Recherche Agronomique du Bénin. 70 :1024.

34. Glèlè Kakaï R.; Sinsin B. (2009). Structural description of two Isoberlinia dominated vegetation types in the Wari-Maro Forest Reserve (Benin). South African Journal of Botany. 75: 43-51. DOI : 10.1016/j.sajb.2008.07.003.

35. Jagoret P. ; Michel I.; Ngnogué T.H.; Lachenaud P.; Snoeck D.; Malézieux E. (2017). Structural characteristics determine productivity in complex cocoa agroforestry systems. Agronomy for Sustainable Development.37:60. Doi:10.1007/s13593-017-0468-0.

36. Etchiké D.A.B.; Ngassoum M.B.; Mapongmetsem P.M .(2020).Potentialités Des Agroforêts Contre Les Changements Climatiques En Zone D'écotone Forêt-Savane Du Cameroun.European Scientific Journal.16(15): 319-350.

37. Dawkins A.C .(1959).The management of natural tropical high-forest, with special reference to Uganda. Commonwealth forestry, Institute University of Oxford. England. Pp 155. 